\title{
ENCOPRESIS IN CHILDREN: AN OVERVIEW OF RECENT FINDINGS
}

\author{
Biljana Vuletic
}

Pediatric Clinic, Department of Gastroenterology, Clinical Centre Kragujevac

Faculty of Medical Sciences, University of Kragujevac, Kragujevac, Serbia

\author{
ENKOPREZA KOD DECE: \\ NAJNOVIJA SAZNANJA \\ Biljana Vuletić \\ Pedijatrijska klinika, Odeljenje za gastroenterologiju, Klinički centar Kragujevac \\ Fakultet medicinskih nauka Univerziteta u Kragujevcu, Kragujevac, Srbija
}

\begin{abstract}
The term 'encopresis', derived from ancient Greek

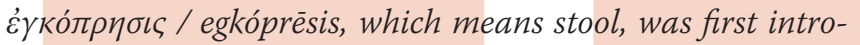
duced in 1926 by Weissenberg to describe the loss of stool in underwear as the faecal equivalent of enuresis. The soiling of underwear is defined as the accidental passage of very small amounts of faeces into underpants. Quantitatively, the content of stool between encopresis and soiling is difficult to determine, and it is especially difficult for parents assess it. Therefore, a new term was adopted - faecal incontinence that encompasses both encopresis and soiling.

Faecal incontinence is defined as the discharge of faeces in socially awkward situations at least once per month in children $\geq 4$ years old. In approximately $95 \%$ of cases, faecal incontinence in children is not organic in origin, but instead appears as a functional gastrointestinal disorder. In $80 \%$ of children with functional faecal incontinence, the symptoms are associated with functional constipation. The remaining $20 \%$ of the cases involve no signs of faecal retention and are defined as non-retentive functional faecal incontinence. This paper aims to present the latest findings within this area of paediatric gastroenterology.
\end{abstract}

Keywords: encopresis, children, incontinence

\section{SAŽETAK}

Termin Encopresis je prvi uveo 1926 god. Weissen-

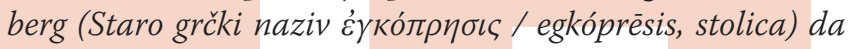
okarakterišs pojavu stolice u donjem vešu kao ekvivalent noćnog mokrenja. Prljanje je definisano posebno, kao nenamerna pasaža vrlo malih količina stolice u ličnom rublju. Kvantitativno, sadržaj stolice između enkopreze i prljanja je teško odrediti, pogotovu roditelji teško mogu učiniti tu procenu, zato je usvojen nov naziv fekalna inkontinencija koji podrazumeva enkoprezu i prljanje zajedno.

Fekalna inkontinencija se definiše kao ispuštanje stolice u socijalno neadekvatnim uslovima najmanje jednom $u$ toku meseca u razvojnom periodu deteta $\geq 4$ godine. $U$ oko 95\% slučajeva, fekalna inkontinecija kod dece nije organskog porekla već se ispoljava kao funkcionalni poremećaj gastrointestinalnog trakta. U $80 \%$ dece sa funkcionalnom fekalnom inkontinencijom simptomi asociraju sa funkcionalnom konstipacijom. U preostalih $20 \%$ slučajeva ona je bez znakova fekalne retencije, definisana kao ne-retentivna funkcionalna fekalna inkontinencija.

Ovaj rad ima za cilj da prikaže najsavremenija saznanja iz ove oblasti dečje gastroenterologije.

Ključne reči: enkopreza, deca, inkontinencija

\section{INTRODUCTION}

The ability to retain faeces has been associated with the study of privacy and order in our culture for approximately 200 years. The ancient Romans spent time together each morning and defecated around each other. This was recorded by the Minister of Finance at the time - Hadrian - who also introduced a tax on "villains" and defended his position with strong arguments. It was only with the invention of the 
Table 1. Rome III criteria for functional defecation disorders in children with a developmental age of at least 4 years

\begin{tabular}{|c|c|}
\hline Suggested terminology & Definition \\
\hline Faecal incontinence & $\begin{array}{l}\text { Passage of stools in an } \\
\text { inappropriate place }\end{array}$ \\
\hline $\begin{array}{l}\text { Organic faecal inconti- } \\
\text { nence }\end{array}$ & $\begin{array}{l}\text { Faecal incontinence result- } \\
\text { ing from } \\
\text { organic disease (e.g., neu- } \\
\text { rological } \\
\text { damage or sphincter ab- } \\
\text { normalities) }\end{array}$ \\
\hline $\begin{array}{l}\text { Functional faecal inconti- } \\
\text { nence }\end{array}$ & $\begin{array}{l}\text { Non-organic disease that } \\
\text { can be subdivided into: }\end{array}$ \\
\hline \multicolumn{2}{|c|}{ - Constipation-associated faecal incontinence (80\%) } \\
\hline \multicolumn{2}{|c|}{$\begin{array}{l}\text { - Non-retentive (non-constipation associated) faecal } \\
\text { incontinence (20\%) }\end{array}$} \\
\hline
\end{tabular}

\section{Definition}

The term 'encopresis', derived from ancient Greek

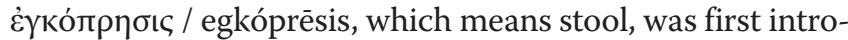
duced in 1926 by Weissenberg as the faecal equivalent of enuresis to describe the loss of stool in underwear $(2,3)$. Later, Bellman defined encopresis as the repeated voluntary or involuntary passage of normal stools into inappropriate places, such as into clothes or onto the floor after the age of 4 years without any organic cause (4). Soiling is specifically defined as an unintentional passage of very small amounts of stool into underwear. Quantitatively, the content of stool between encopresis and soiling is not easy to determine, and it can be especially difficult for parents to assess it. Therefore, a new term was adopted - faecal incontinence - that encompasses both encopresis and soiling $(5,6)$. Both conditions are commonly associated with functional constipation. At first, it was thought that all children with faecal incontinence had constipation, but subsequent findings revealed that faecal incontinence can occur without signs of constipation, which created confusion in the interpretation of the problem (7). In some parts of the world, doctors consider encopresis to be a mental disorder, and others use the term 'encopresis' in relation to soiling or faecal incontinence. Whatever it is called, the situation is very unpleasant for the child, and it is difficult for parents to accept the same. Due to the absence of a consensus on the interpretations of encopresis and other functional disorders of the gastrointestinal tract, a group of experts in paediatric gastroenterology established the criteria for childhood functional gastrointestinal disorders, known as Roma II, in the year 2000. Disorders of defecation included: functional constipation, functional faecal retention and functional non-retentive faecal soiling. Later, numerous studies evaluated the acceptability of these types of classifications in clinical practice, and it became clear that the first paediatric Roma criteria were too restrictive and were insufficient for many patients with specific functional gastrointestinal diseases such as constipation and abdominal pain (8). Therefore, the terms were redefined in 2006 as part of a set of criteria known as Roma III; the term 'faecal incontinence' was adopted as a substitute for encopresis and soiling to indicate organic faecal incontinence or functional faecal incontinence (9-11). Table 1.

The Roma III criteria are currently used to define functional faecal incontinence. Table 2.

\section{Epidemiology}

The prevalence of functional faecal incontinence has been found to vary between 1 and $4 \%$ in children $>4$ years old and between 1 and $2 \%$ in 7 -year-old children. The rate in children aged 10 and 11 years was found to be $1.6 \%$. This condition was observed three to six times more often in boys than in girls (3:1 to $6: 1)(12-14)$.

Children with functional non-retentive faecal incontinence (FNRFI) experience faecal incontinence as their only symptom. In contrast to children with functional constipation, they have normal stool consistencies. Symptoms such as abdominal pain, rectal bleeding, difficulty defecating, poor appetite, palpable abdominal masses and palpable rectal masses are significantly less common in these children compared to those with constipation (15). Nocturnal faecal incontinence is less common in children with FNRFI (12\%) compared to children with constipation (30\%) (9), while the frequency of diurnal and nocturnal enuresis in them is higher

Table 2. Rome III criteria for functional faecal incontinence in children with a developmental age of at least 4 years

\begin{tabular}{ll}
\hline Suggested terminology & Definition \\
\hline & Most fulfil $\geq 2$ criteria at least once per week for $\geq 2$ months prior to diagnosis, with insufficient \\
criteria for the diagnosis of irritable bowel syndrome: \\
$1 . \leq 3$ defecations in the toilet per week \\
$2 . \geq 1$ episode of faecal incontinence per week \\
3unctional constipation & 4. History of retentive posturing or excessive volitional stool retention \\
& 5. Presence of a large faecal mass in the rectum \\
& 6. History of large-diameter stools, which may obstruct the toilet \\
\hline Must fulfil all of the following for $\geq 2$ months prior to diagnosis: \\
1. Defecation into places inappropriate to the social context at least once per month \\
2. No evidence of an inflammatory, anatomic, metabolic, or neoplastic process that explains the \\
subject's symptoms \\
3. No evidence of faecal retention \\
\hline
\end{tabular}


(40-45\%) than in children with constipation (25-29\%), which suggests that children with FNRFI lack the normal physiological stimuli needed to go to the toilet (16-18). These children attended paediatric clinics for the first time at an older age than those who had constipation (on average 9.2:6.5 years). It is surprising that only $29 \%$ of these children had ever visited a doctor to address the problem $(19,20)$. Very often, FNRFI is not recognized as a distinct clinical entity by general practitioners and paediatricians, which frequently results in inadequate treatment with a negative response in the follow-up and deepens the problem. Approximately $30-40 \%$ of children with FNRFI have never been toilet trained successfully, while the majority have been completely toilet trained before and regressed to incontinence. Children may blame the occurrence of faecal incontinence on "not having time to go to the toilet", or they may state that "I could not leave my computer game" or "I felt the urge to go, but I was too late".

\section{Pathophysiology}

The exact mechanism of FNRFI is generally unknown. In the literature, there are controversial ideas regarding its aetiology that focus on anorectal motility and sensation, genetics, and mental and psychiatric disorders. In any case, it is complex and multifactorial. Defecation is a complex action that takes place between the pelvic floor muscles, autonomic and somatic nervous systems and anal sphincter muscles. It consists of involuntary and voluntary actions that are both reflexive in nature. In infants and young children, myelination of the corticospinal tract is not yet complete, so they lack the ability to volitionally defecate. In most cases, this myelination is complete at the age of approximately 18 months, although the exact age can vary. At the age of 3 years, $98 \%$ of children are 'clean'. Girls tend to gain control sooner due to their accelerated maturation, which is also reflected in their earlier bladder control. The process of control over defecation and urination is an issue of development and cannot be accelerated by intensive toilet training. A child's initiative is the only proven indicator that they have developed the pathways needed to desire to be "clean" and "dry". Abnormal dynamics of defecation are one of the factors involved in the pathophysiology of faecal incontinence. The use of so-called radiopaque markers (colonic transit time) and anorectal manometry enable the evaluation of sphincter function, while a rectal barostat is a tool used to investigate rectal compliance and sensation. Pathological findings on colonic transit time (CTT) were found in approximately $50 \%$ of constipated children, while findings within the normal range were found in all of the children with FNRFI. This points to the presence of normal intestinal motility in these children $(21,22)$. In assessing anorectal function, anorectal manometry has indicated that there is no significant damage to anorectal sensorimotor function in these children compared to healthy volunteers $(23,24)$. The rectal barostat method has indicated that an increase in rectal compliance, rather than a reduction in rectal sensitivity, is the pathophysiological mechanism in functional constipation in children. In children with high rectal compliance, a large- volume stool is necessary to "trigger" an immediate sensation. It is not known whether genetic predisposition plays a crucial role in this, but in approximately $20 \%$ of children with FNRFI, a positive family history was reported. It is questionable whether it is a matter of genetic tendency or if it is the result of psychosocial and/or environmental effects, as psychiatrists have considered incontinence to be a result of emotional instability (conduct disorders, reduced alertness, lack of will, hyperactivity, poor social adaptability, learning difficulties), which is reflected in impulsive and unconscious defecation. Paediatricians believe that psychological problems are secondary and are a result of social incapacitation in children with faecal incontinence. Frustration and shame due to the inability to control defecation and occasional incontinence lead to comorbid psychological disorders in these children, which can be improved after successful treatment (25).

\section{Evaluation}

Normal CTT (90\%) results with anamnesis and a normal stool appearance without "faecal masses" in the physical findings are sufficient for a differential diagnosis. Other tests such as anorectal manometry, rectal barostat testing and MRI of the spinal cord are rarely needed (26).

The medical history involves questions about the frequency and size of the child's stool, rectal bleeding, abdominal pain, painful defecation, etc. It is important to ask for the timing of defecation problems - daytime or nocturnal - and consider the situations associated with stool retention (playing outside, TV or computer use). FNRFI in most children usually occurs after school and before bedtime, while nocturnal faecal incontinence is associated with severe constipation. The child's nutritional history is also important, as is information concerning their bowel habits. Urinary tract abnormalities (enuresis), growth, drugs, neuromuscular development, any family history of defecation disorders, and information about psychological problems in the child and their family (birth of twins, parental divorce, illness in the family) must be considered. $(27,28)$

Each child with a defecation disorder must undergo thorough physical and neurological examinations. A perianal inspection provides important information on the position of the anus, rectal faeces, redness, dermatitis, eczema, fissures, haemorrhoids, scars, etc. Digital anorectal examination is an invaluable tool in the assessment of perianal sensation, anal tone, rectal size, faecal volume and consistency, and voluntarily activated anal sphincter contraction and relaxation (29). No anorectal physiologic abnormalities were present in children with FNRFI (30).

Warning signs that should result in increased attention are the absence of meconium passage, early occurrences of constipation, an empty rectal ampulla, refractory constipation, etc. Disturbing neurological signs include motor and sensory dysfunction in the lower extremities, abnormal reflex activity and anorectal sensation. An MRI of the spinal cord is justified in these cases (31). 


\section{Treatment}

In contrast with children with faecal incontinence caused by functional constipation, patients with FNRFI should not be treated with laxatives $(32,33)$. Education, toilet training, and positive motivation are the cornerstones of treatment for these patients (34). Children and their parents should be prepared for a long-term process with many ups and downs. The aim is to prevent accidents and achieve regular bowel emptying, emphasizing the importance of immediately going to the toilet $(35,36)$. In addition, the education of both children and their parents in colorectal physiology, defecation and faecal incontinence can help significantly. Finally, parents should know that children are not always aware of their faecal accidents; they should mitigate their child's guilt and explain the prevalence of the disorder and how cooperation is needed to treat it. Meticulously kept records and strict toilet training performed 3 times each day within 5 minutes after meals are the most effective methods (37-39). Small gifts can further increase motivation (40-42). No signs of improvement were noticed in these patients after the administration of laxatives, while the longterm administration of laxatives is required in children with constipation (43). The effects of loperamide, which increases the pressure in the internal anal sphincter and/or reduces rectal contraction, should be examined in paediatric patients (44). Biofeedback training has no additional effect in these groups of children (45). Successful treatment of children with FNRFI leads to improvements in most patients, which suggests that these children should be treated primarily in paediatric rather than psychiatric clinics and consulting rooms (46). The course of treatment is lengthy, symptoms often persist for a long time and relapses are possible.

\section{CONCLUSION}

Faecal incontinence rarely results from FNRFI, but it is crucial to make a differential diagnosis between FNRFI and functional constipation because each requires different approaches and treatments. A proper diagnosis is made through a case history and physical examination and is confirmed by the colonic transit time. Changes in behaviour designed to educate both children and their parents along with toilet training are the most effective therapies for FNRFI, while cases of functional constipation require long-term treatment with laxatives in addition to toilet training and diet modification.

The high percentage of relapses observed indicates the importance of intensive monitoring and follow-up for these patients.

\section{REFERENCES}

1. Kratky - Dunitz M, Scheer P. J. Encopresis. Monatsschr Kinderhelikid 1988;136:630-35

2. von Gontard A. Encopresis. In: Rey J. editor. IACAPAP Textbook of Child and Adolescent Mental Health, online; 2012.http://iacapap.org/iacapap-textbook-ofchild-andadolescent-mental-health

3. Sambach H, Equit M, El Khatib D, Schreiner-Zink S, Von Gontard A. Therapieresistente Harninkontinenz undEnur esis:Gruppenblasenschulung. Monatsschrift Kinderheilkd 2011;159:565e71

4. Bellman M. Studies on encopresis. Acta Paediatr Scand 1966 ;(Suppl. 170):1

5. The Paris Consensus on Childhood ConstipationTerminology (PACCT) Group. Journal of Pediatric Gastroenterology and Nutrition 2005;40:273-275

6. Rasquin A, Di Lorenzo C, Forbes D, Guiraldes E, Hyams JS,Staiano A, et al. Childhood functional gastrointestinal disorders:child/adolescent. Gastroenterology 2006;130(5):1527e37

7. Benninga MA, Buller HA, Heymans HS, Tytgat GN,Taminiau JA. Is encopresis always the result of constipation?Arch Dis Child 1994;71(3):186e93

8. Loening - Baucke V. Fukctional Fecal Retention With Encopresis in Childhood. J. Pediatr Gatroenterol Nutr 2004;38:79-84

9. Clinical Practice Guideline, Evaluation and Treatment of Constipation in Infants and children: Recommendation of the North American Society for Pediatric Gastroenterology, Hepatology and Nutrition. Gatroenterology 2006;43(3):e 1-13

10. Burgers R, Benninga M. A. Fnctional Nonretentive Fecal Incontinence in Children: A Frustrating and Long - lasting Clinical Entity.J. Pediatr Gatroenterol Nutr 2009;48(2):S 98-100

11. Papadopoulou A. Functional Gastrointestinal Disorders in Infancy and Childhood:Rome III Diagnostic Criteria. The 2nd South Easten European Pediatric Gastroenterology Meeting, 2011 Bled;Abstract book:3-8

12. Bongers MB, Tabbers M. M. Beninga M.A. Functional nonretentive fecal incontinence in children. J. Pediatr Gatroenterol Nutr 2007; 44:5-13

13. Van der Wal, M. F,Beninga M.A, Hirasing R. A.The prevalence of encopresis in a multicultural population. J. Pediatr Gatroenterol Nutr 2005;40(3):345-48

14. Rajindrajith S, Devanarayana NM, Benninga MA. Constipation-associated and nonretentive fecal incontinence inchildren and adolescents: an epidemiological survey in Sri Lanka. J Pediatr Gastroenterol Nutr 2010;51(4):472e6

15. Michail S, Broxon E, Mezoff A, Prend D, Hitch D. A. Rare Rectal Tumor presenting With Encopresis and Rectal Bleeding in a Three-Year - Old Girl: Case Report and Review of the Liteature. J. Pediatr Gatroenterol Nutr 2002;35(4):579-82.

16. Von Gontard A, Baeyens D, Van Hoecke E, Warzak WJ,Bachmann C. Psychological and psychiatric issues in urinary and fecal incontinence. J Urol 2011;185(4):1432e6

17. Burgers R, de Jong TP, Visser M, Di Lorenzo C, Dijkgraaf MG,Benninga MA. Functional defecation disorders in children with lower urinary tract symptoms. J Urol 2012;189(5):1886e91 
18. Austin PF, Bauer SB, Bower W, Chase J, Franco I, Hoebeke P,et al. The standardization of terminology of lower urinarytract function in children and adolescents: update report from the standardization committee of the International Children's Continence Society. Neurourol Urodyn 2015 http://dx.doi.org/10.1002/ nau.22751. [E pub ahead of print]

19. Fishman L, Rappaport L, Consineau Dand Nurko S. Early Constipation and Toilet Training in Children With Encopresis. J. Pediatr Gatroenterol Nutr 2002;54(4):384-87

20. Pakarinen M, Koivuselo A and Rintela R. Functional Fecal Soiling Withaout Constipation, Organic Cause or Neuropsychiatric Disorders? J. Pediatr Gatroenterol Nutr 2006;43(2):205-8

21. Gutierrez C, Marco A, Nogales and Tebar R. Total and Segmental Colonic Transit Time and Anorectal Manometry in Children With Chronic Idiopathic Constipation. J. Pediatr Gatroenterol Nutr 2002;35(1):30-38

22. Benninga M. A, BullerH. A. Tytgat G.N.J. Akkermans L. M.Bossuyt P. M.Taminiau J. A. J. M. Colinic Transit Time in Constipated Children: Does Pediatric Slow Transit Constipation Exist ? J. Pediatr Gatroenterol Nutr 1996;23(3):pp.241-51

23. Wald A, Chandra R,Chiphonis D and Gabel S. Anorectal Function and Continence Mechanisms in Childhood Encopresis. J. Pediatr Gatroenterol Nutr 1986;5(3):345-51

24. GertekenJ.T.CocjinJ,PehlivanovN,Danda C and Hyman P.E. Comorbidities Associated with Constipation in Children Referred for Colon Manometry May Mask Fuctional Diagnoses. J. Pediatr Gatroenterol Nutr 2005;41(5):328-31

25. Von Gontard A, Niemczyk J, Weber M, Equit M. Specificbehavioral comorbidity in a large sample of children withfunctional incontinence: report of 1,001 cases. Neurourol Urodyn 2015;34(8):763e8

26. Burgers R, Benninga M. A. Fnctional Nonretentive Fecal Incontinence in Children: A Frustrating and Long - lasting Clinical Entity. J. Pediatr Gatroenterol Nutr 2009;48(2):S 98-100

27. Rajindrajith S, Devanarayana NM, Benninga MA. Reviewarticle: faecal incontinence in children: epidemiology, pathophysiology, clinical evaluation and management.Aliment Pharmacol Ther 2013;37(1):37e48

28. Von Gontard A. Urinary incontinence in children with specialneeds. Nat Rev Urol 2013;10(11):667e74

29. Burgers R, de Jong TPVM, Benninga MA. Rectal examinationin children: digital versus transabdominal ultrasound. J Urol2013;190(2):667e72

30. Sentovich S. M. Kaufman S. S, Cali R. L. Falk P. M, Blatchford G. J. Pudendal Nerve Fuction in Normal and Encopretic Children.J. Pediatr Gatroenterol Nutr 1998;26(1):pp 70-72

31. Bekkali N-L-H, Hagebeuk EEO, Bongers MEJ, van Rijn RR, VanWijk MP, Liem O, et al. Magnetic resonance imaging of the lumbosacral spine in children with chronic constipation or non-retentive fecal incontinence: a prospective study. J Pediatr 2010;156(3):461e5
32. Koppen IJN, von Gontard A, Chase J, Cooper C.S, RittigC.S, Bauer S.B, Homsy Y, Yang S.S, Benninga M.A. Management of functional nonretentive fecal incontinence in children: Recommendations from the International Children's Continence Society, Journal of Pediatric Urology (2015), http://dx.doi.org/10.1016/j.jpurol.2015.09.008

33. Burgers R, Reitsma JB, Bongers ME, de Lorijn F, Benninga MA.Functional nonretentive fecal incontinence: do enemas help? J Pediatr 2012;162(5):1023e7

34. Borowitz S, Cox D.J. Suthphen J. L and Kovatchew B. Treatment of Children Encopresis - A Randomised Trial Comparing Three treatment Protocols. J. Pediatr Gatroenterol Nutr 2002;34(4):377- 84

35. Corbett P, Denny A, Dick K, Malone PS, Griffin S, Stanton MP.Peristeen integrated transanal irrigation system successfullytreats faecal incontinence in children. J Pediatr Urol 2014;10(2):219e22

36. Nasher O, Hill RE, Peeraully R, Wright A, Singh SJ. Peristeen transanal irrigation system for paediatric faecal incontinence: a single centre experience. Int J Pediatr 2014:954315

37. Warzak WJ, Forcino SS, Sanberg SA, Gross AC. Advancing Continence in Typically Developing Children: Adapting the Procedures of Foxx and Azirin for Primary Care. J Dev Behav Pediatr 2016 ;37(1):83-7

38. Equit M, Sambach H, Niemczyk J, Gontard A von. Urinary and fecal incontinence: a training program for children and adolescents.Boston: Hogrefe Publishing; 2015. p. 209

39. Koppen IJN, Lammers LA, Benninga MA, Tabbers MM. Managementof functional constipation in children: therapy inpractice. Paediatr Drugs 2015;17(5):349e60

40. Lowery S. Srour J. W. Whitehead W. E and Schuster M. Habit Training as Treatment of Encopres is Secondary to Chronic Constipation. J.Pediatr Gatroenterol Nutr 1985;4(3):396-401

41. Kaugars S. A. Silverman A, Kinservik M, Heinze S, Reinemann L. Sandre Mat al.Families Perspectives on the Effect of Constipation and Fecal Incontinence on Quality of Life. JPGN 2010;53(6):747-52

42. van Tilburg, Miranda A. L, Squires M, Nanette B. M, Benninga M. A, at al. Parental Knowledge of Fecal Incontinence in children. JPGN 2012; Post acceptance.

43. Tabbers MM, DiLorenzo C, Berger MY, Faure C, LangendamMW,Nurko $S$, et al. Evaluation and treatment of functional constipationin infants and children: evidencebased recommendationsfrom ESPGHAN and NASPGHAN. J Pediatr Gastroenterol Nutr 2014;58(2):258e74

44. Voskuijl W. P. van Ginkel, Taminiau J. A.and Benninga A. M. Loperamide Suppositories in an Adolescent with Childhood - Onset Functional Non-retentive Fecal Soiling. J. Pediatr Gatroenterol Nutr 2003;37(2):198-200

45. Wald A, Chandra R, Gabel S and Chiponis D. Evaluation of Biofeedback in Childhood Encopresis. J.Pediatr Gatroenterol Nutr 1987;6(4):553-8

46. Borch L, Hagstroem S, Bower WF, Siggaard Rittig C, Rittig S.Bladder and bowel dysfunction and the resolution of urinary incontinence with successful management of bowel symptomsin children. Acta Paediatr 2013;102(5):e215e20 